\title{
O sacramento assembleia: Teologia mistagógica da comunidade celebrante
}

\author{
Orientador: Luiz Fernando Ribeiro Santana \\ Doutorando: Gustavo Correa Cola \\ Área de Concentração: Teologia Sistemático-Pastoral \\ Linha de Pesquisa: Fé e Cultura \\ Projeto de Pesquisa: Questões atuais de Teologia Litúrgica
}

A construção de uma atualizada e orgânica teologia da assembleia litúrgica, em diálogo com a experiência concreta e os desafios vividos pelas comunidades que se reúnem para a celebração do mistério da fé, é a pretensão desta pesquisa. Ancorados no fato de que, para o cristianismo, a assembleia cultual assume um significado de todo particular e reveste-se de uma responsabilidade ímpar, pois é sacramento - sinal evocativo, mas, ao mesmo tempo, experiência daquilo que é evocado -, aproximamo-nos de sua realidade munidos de uma sensibilidade particular, que leve em conta tal especificidade. A mistagogia, recurso pedagógico-experimental de acesso ao mistério cristão, empresta-nos, além da inspiração espiritual, a metodologia integradora e a linguagem simbólica.

Palavras-chave: Teologia litúrgica. Assembleia. Igreja. 